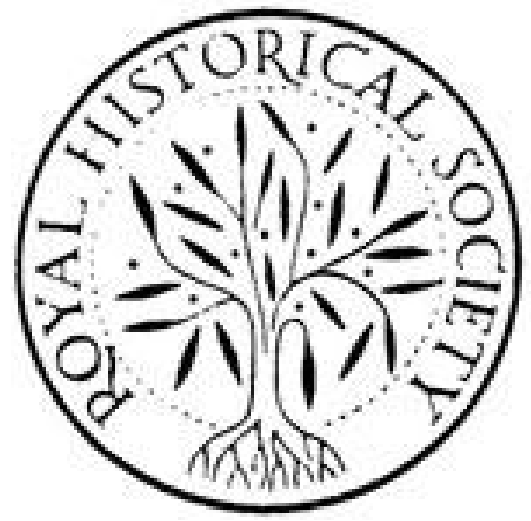

Duelling and Militarism

Author(s): A. Forbes Sieveking

Source: Transactions of the Royal Historical Society, Vol. 11 (1917), pp. 165-184

Published by: Cambridge University Press on behalf of the Royal Historical Society

Stable URL: http://www.jstor.org/stable/3678440

Accessed: 26-06-2016 04:11 UTC

Your use of the JSTOR archive indicates your acceptance of the Terms \& Conditions of Use, available at

http://about.jstor.org/terms

JSTOR is a not-for-profit service that helps scholars, researchers, and students discover, use, and build upon a wide range of content in a trusted digital archive. We use information technology and tools to increase productivity and facilitate new forms of scholarship. For more information about JSTOR, please contact support@jstor.org.

Cambridge University Press, Royal Historical Society are collaborating with JSTOR to digitize, preserve and extend access to Transactions of the Royal Historical Society 


\section{DUELLING AND MILITARISM}

By A. FORBES SIEVEKING, F.S.A., F.R.Hist. Soc.

\section{Read January I8, I9I7}

IT is not the object of this paper to suggest that there is any historical foundation for the association of a social or even a national practice of duelling with the more recent political manifestation, which is usually defined according to our individual political beliefs ; far less is it my intention to express any opinion of my own on the advantages or evils of a resort to arms as a means of settling the differences that arise between individuals or nations.

If we were to look in dictionaries or bibliographies for the exposition of my title you would find that 'Duelling' is associated with 'Arms,' ' Blood Feuds,' ' Fencing,' ' Trial by Combat,' 'Trial by Ordeal,' 'Social Life,' 'Mediæval Law,' and 'War' ; whilst 'Militarism' connotes 'Armies' and 'Armaments,' always in an evil sense-the abuse of the military power. At the same time 'Militarism' has its admirers and its advocates. Thus Maximilian Harden can write as follows in the Zukunft:

'Militarism is a form of civilisation and a state of mind. It presses for ever stronger armaments, and accustoms even the ordinary citizen to the idea that weapons alone can settle a strife of peoples, and that any other tool is unworthy and useless. Heroism and military virtue can flourish without militarism, but it alone guarantees the constant readiness of all the limbs of the people's body for rapid transition from peace to war. It is because militarism favours the temptation to war, and must either extend its depredations far and wide, or be rooted out absolutely, that the war is to continue until militarism has been destroyed. That is what all the enemies of the German Empire say out loud, and what all neutral Powers say in whispers.' 1

1 The Times, October 27, r916. It is significant that the first instance of the use of the word in the 'New English Dictionary' from 
My purpose in this paper is merely to indicate the close connection that has always existed between the practice of arms and their use in single combat of an authorised or unauthorised nature. The very habit of wearing arms implies the prevalence of private warfare; and we know that the armed borderers and feudal retainers furnished the bulk of the national armies of the Middle Ages. But from a much earlier period we find acts both of private and national warfare taking the formal shape of single combat in accordance with the judicial or social custom observed or at least recognised throughout mediæval Europe. In the same period the abuse of weapons prepared for national or self-defence, and the fantastic extravagances of the military art, under the cloak of chivalry, had called for repression at the hands of Church and State. But though feudalism and chivalry were extinguished, and warfare brought under the statutory discipline of the State, it was found impracticable to deal with individual turbulence or egotism on these lines. The result has been a refinement of the single combat in the form of a punctilious meeting which has survived to the present day in almost every country but our own.

Duelling, then, has passed through various stages or phases before attaining the sense in which it is most familiar to us, viz. the reparation of or satisfaction for outraged or wounded personal honour, for which the law provides no remedy, or one that is considered inadequate to wipe out the insult or offence.

In its earliest or representative stage, as amongst the ancient Greeks and Romans, the duel or 'certamen singulare' (except in a few cases of fights for spoil or plunder) was fought by certain picked champions chosen to represent the Daily Telegraph of April 28, I 864 (in connection with Garibaldi) speaks of 'an army yet untainted with that disease of modern times known under the sinister name of Militarism,' and the second instance, in I868, speaks of 'Prussian militarism,' but Millingen in his History of Duels (I 84 I), has: 'Militarism is the child of Feudalism.' 
a nation, tribe, or clan, and the result of the combat was held to decide the question of superiority between the larger hosts ranged in battle. Such were the innumerable contests between the heroes of the 'Iliad '-generally conducted under the supervision of the presiding deity of either side. There was no idea amongst the ancients that an insult demanding reparation could be conveyed by language, however strong; and the accusation of lying carried no stigma with it, but, on the contrary, would be regarded rather as a compliment by the Greeks, as indicating superior wit and cleverness on the part of the so-called liar. A cursory glance through the admirable article 'Monomachia' in d'Aremberg and Saglio's 'Dictionary of Antiquities' reveals to us that the very fabric of the 'Iliad ' is woven out of duels of this nature. Monsieur Paul Gerard, indeed, is of opinion that the 'monomachia' forms the primordial and fundamental element of the 'Epopee.' The combats of Patroclus with Sarpedon and Hector, of Achilles with Hector, Diomedes and Glaucus (where challenges are accompanied with the strongest vituperation or coarsest insults), of Hector and Ajax, and Paris and Menelaus, are some of the leading 'certamina singularia' (as the Romans called them), which prove that the duel was familiar to the Greeks in the representative sense of chosen champions of their nation in battle.

It will be understood, of course, that the single combat was not a national custom peculiar to the Greeks and Romans, but is found in other contemporary civilisations, as in the familiar instances of the combats between David and Goliath, \&c., preserved in Western and Eastern history alike. ${ }^{1}$

By the Romans, to accept a challenge to fight a private duel would have been regarded as an act of insanity or moral cowardice, and to leave the world in this way a far less satisfactory means of exit than suicide. The challenges

${ }^{1}$ Cf. Corpus Juris Canonici (1747), i. 389. 
now and then issued to a Roman commander by the Gauls or some other Celtic tribe to fight a duel unconnected with a battle were always treated with contempt. So when we read, as we do in Plutarch, that Marcellus never declined a challenge to single combat, and never accepted without killing his challenger, we must take this as meaning that the combat was either fought in battle itself, or, as is described later on in the same Life, with the Gallic commander or king advancing in front of the army drawn up in battle array. ${ }^{1}$

The Puritan Jeremy Collier may be quoted on this point :

'This venturing All against Nothing puts me in mind of Mark Antony, who after he had lost the Battle at Actium and was penned up in Alexandria would needs send Augustus a Challenge. Cæsar's answer was, that if he was weary of living, there were other ways of Dispatch besides fighting him: and for his part he should not trouble himself to be his Executioner. Antony, I suppose, thought the return reasonable; and in a short time did his own business.'

The next phase of duelling was the judicial duel, or Judicium Dei, more familiar to us as the 'Wager of Battle' or 'Trial by Combat,' which remained in force for over ten centuries, and was universally adopted in Europe. This sprang out of the earlier Ordeal, of which it was really a development, and was based upon the superstitious idea that God was on the side of the conqueror-and that Might proved Right. Selden supported it on the ground that if any war was lawful, duelling was also. 'War is lawful,' he argued, ' since God is the only Judge between two that are supreme, such as two kings or princes. Now if a difference happened between two subjects, and it cannot be decided by human testimony, why may they not put it to God to judge between them by the permission of the Prince ?'2 And in Selden's question we find stated the

1 Plutarch's Lives, 'Marcellus' (Clough's ed. Appendix ii. 239 and 244).

2 Selden, Table-Talk, P. I 47. Cf. F. Patetta, Le Ordalie (I 890), passim. 
whole theory and principle of the trial by combat. This differed from the Ordalium, or Ordeal, in that the latter was the trial of one person under accusation of a crime, whereas the former was to settle an action, dispute, or later on a point of honour between two individuals-the ordeal was between God and man; the duel (or Duorum Bellum) was between man and man (with God as the Judge or Umpire).

It is useless to enlarge on the mediaeval formalities of making war which were still to some extent preserved in Selden's time. The latter was well aware that Plantagenet kings regarded themselves as pitted against their ' adversary of France' to obtain satisfaction for some claim or injury. The nations were required to make these royal quarrels their own, and from this point of view, feudalism may be regarded as a notable incentive to national warfare. For in order to prepare against surprise, and also to provide the nucleus of a national levy, kings set on foot that profession of arms which is commonly, though not always justly, associated with the practice of duelling and the cult of militarism in later times.

In the earliest annals of the mediaeval period, we find the formal duel rife amongst the continental nations who had overthrown the Roman sway. Gibbon analyses the Judicium Dei (or judicial combat) at the beginning of the sixth century A.D. as sanctioned by the laws of the Franks, the Merovingians, the Burgundians (represented by Gundobald), the Alemanni, the Bavarians, and other barbarians (Ostrogoths, Visigoths, \&c.).

The Judicium Dei was introduced into Gaul by the Burgundians, whose legislator Gundobald, in his original edict, published at Lyons A.D. 50r, establishes and justifies the use of the judicial combat.

Three hundred years later Agobard, Bishop of Lyons, solicited Lewis the Pious to abolish the law of an Arian tyrant, and relates the conversation of Gundobald and Avitus. 
'Is it not true,' the King asks the Bishop, 'that the event of national wars and combats is directed by the judgment of God, and that His providence awards the victory to the juster cause ?' 1

A greater thinker than this-Dante, five hundred years afterward asked and answered the same question almost in identical language in his 'De Monarchia.' 2 Upon one point, indeed, Dante is intensely modern-one might hazard the epithet British-in his curious 'sporting' parallel of the Judicium Dei with the pagan 'Palaestra.' Indeed, in this spirit of sportsmanship, Dante quoted with approval Cicero's commendation of Chrysippus, who expressly rules out 'tripping up' competitors, while he chooses for his illustrations the combats between Hercules and Antæus, and Atalantes and Hippomenes.

But to go back to our barbarian nationalists, we find ample proof in historical literature that the duel flourished exceedingly throughout the ' dark ages.'

'By such arguments ' (as those of Gundobald), says Gibbon, ' the absurd and cruel practice of judicial duels, which had been peculiar to some tribes of Germany, was propagated and established in all the monarchies of Europe, from Sicily to the Baltic. At the end of ten centuries, the reign of legal violence was not totally extinguished; and the ineffectual censures of Saints, of Popes, and of Synods, may seem to prove that the influence of superstition is weakened by its unnatural alliance with reason and humanity. . . . The tribunals were stained with the blood, perhaps, of innocent and respectable citizens; the law, which, perhaps, now favours the rich, then yielded to the strong; and the old, the feeble, and the infirm were compelled either to renounce their fairest claims and possessions, to sustain the dangers of an unequal conflict, or to trust to the doubtful aid of a mercenary champion.'

In all this welter of bloody reprisals for public or private offences, one saving feature may be discerned by some-

1 Gibbon, Decline and Fall (ed. Bury), iv. 127 and 128.

2 F. J. Church's translation (1879), p. 63. 
the fearlessness and personal bravery and endurance of combatants or champions who engaged in these encounters. It would be invidious to suggest that this quality of courage was more conspicuous in one nation than another, but it is noticeable that Englishmen have enjoyed an almost unenviable reputation in this respect. At least this seems to have been a national trait, and it has never needed to be maintained by social codes or dynastic devices. Similarly the temperament of Celtic nations has made them careless of the consequences of personal encounters which they have been always ready to provoke. It is curious to find that in a more barbarous age the courage of the tribesmen was fostered by a process of inoculation.

Jordanes, in his 'Gothic History,' A.D. 55I, tells how the Huns

' are cruel to their children on the very day they are born. For they cut the cheeks of the males with a sword, so that before they receive the nourishment of milk they may learn to endure wounds. Hence they grow old beardless, and their young men are without comeliness, because a face furrowed by the sword spoils by its scars the natural beauty of a beard . . . their firm-set necks are ever erect in pride-though they live in the form of men, they have the cruelty of wild beasts.'

Those who remember how accurately the historian's remarks about the scars and furrows on the face bring before us the appearance of the members of the Duelling Corps of a German University will perhaps wonder whether the Huns had left the traditions and traces of their mutilating the cheeks of their offspring during their early excursions among the primitive inhabitants of Germany. ${ }^{1}$

Although in most countries a woman could only fight through her champion, the Germans allowed a woman to wage a judicial combat even with her husband. In Hans Talhofer's 'Kampfbuch' (I443), and again in Gerhard's

1 Several eminent scholars whom the author has consulted on the subject are unable to throw any light on the devolution of the custom described by Jordanes. Cf. Hodgkin, Italy, i. 96. 
'Tractatio de judicio duellico' (I735), we find described in great detail, and accompanied by engravings, the process of a duel of this sort as it was carried out in the district of Würzburg. This was a development of what was known as the Kolbengericht, or club-judgment, from the weapons employed. Here the man was placed up to the waist in a pit armed with a club or stick, the woman being also armed with a stick, to which was attached a stone.

Against the statement of $\mathrm{H}$. C. Lea ${ }^{\mathbf{1}}$ (on the authority of laws and other historical documents) that the AngloSaxons knew not the duel, we can scarcely rely on the interesting story told by William of Malmesbury of King Edgar's challenge to Kenneth of Scotland, who had made wounding reference to the King's insignificance. ${ }^{2}$

Such an incident might have happened in any country, whether its laws and customs recognised the judicial combat as a regular institution or not; but with the coming of the Normans we know that the 'battle' plays a very notable part in judicial procedure. Hitherto in England and in Teutonic and Scandinavian countries generally the solidarity of the kindred, expressed by the judicial 'wergild ' or compensation for bloodshed, exercised a wholesome restraint on the prevalent tribal custom of blood-vengeance as a justification for blood-feuds. ${ }^{3}$ But long before the Conquest the tribal system had become disintegrated and a feudal system was taking its place.

Students of the early French chronicles will recall how Wace, the Anglo-Norman Jongleur, in the reign of Henry II, in his 'Roman de Rou,' that worthy comment on the Bayeux tapestry, sings the historic field of Senlac or Hastings. How Hugues Maignot (to cite Thierry's version) came in William the Norman's name to call upon Harold to resign his royalty, or to refer it to the Pope's

1 Superstition and Force (1892), Chap. ii. p. II4, 'Origin of the Judicial Duel.'

2 Sharon Turner, Hist. of Anglo-Saxons, ii. 269.

3 B. Phillpotts, Kindred and Clan, p. 6. 
arbitration, or to let it be determined by the issue of a single combat.

Had this combat been waged, we know from Mr. George Neilson's valuable 'Trial by Combat' the exact procedure that would have been followed out between the two champions.

The third phase of duelling may be called the Chivalrous type of single combat, dependent as it was upon that curious spiritual blend of religious mysticism, of love or gallantry towards women, and of that dawning sense of duty for the strong to protect the weak and of the rise of humanity towards our fellow-creatures. We know that chivalry reached maturity in the later Middle Ages as one of the products of the Crusades, and may be said to have culminated in the civilisation of the Renaissance. Its alleged observance in an earlier period, which has been widely credited, may perhaps be traced to the late fourteenthcentury forgery attributed to Ingulph, Abbot of Croyland. Some form of tournament may certainly be traced back to a comparatively early date; but the point that is connected with this phase of the chivalrous duel is found in the details regulating its procedure, even for a judicial purpose.

It is perhaps not surprising, in view of the recognition or regularisation of the duel by the State in those early times, that private and unauthorised encounters should have been viewed with disfavour in official quarters. In fact, no sooner is this personal duel well established, than it is prohibited. ${ }^{1}$ Many instances could be given of such prohibitions from the fifteenth century onwards and various reasons might be suggested for this attitude. The waste of life and national strength must have been a matter of concern to ministers, while the habit of carrying and using arms was not viewed with favour by a government unfortified with a standing army or police force.

1 The intervention of the Crown in the duel of the Dukes of Hereford and Norfolk (I398) is well known. 
The vogue of the private duel in Germany can be traced back to the year I500. It was practised in all ranks of society, from princes to peasants. By the middle of the sixteenth century the duel had become not a custom merely, but a compulsory obligation which reached its culminating point in the seventeenth century. The habit became a rage, a mania, a disease-and men slew one another for the lust of slaughter. In Spain, Italy, and France the Church pronounced against it in Councils, and kings condemned it in edicts, but quite in vain. We have only to consult the pages of Brantôme's 'Discours sur les Duels' to see the point which the epidemic had reached amongst the Latin nations of Europe.

Francis I not only encouraged it throughout his dominions, but himself set the example by challenging to a personal duel the Emperor Charles V, in order to 'defend his honour with his body and his life.'

The tournament in Tudor days had become only a spectacular survival, and the knight was superseded by the strutting swashbuckler, who ushers in the last phase of the duel ; this might be called the Egoistic stage, being determined not by the law and custom of the land, but by the irresponsible interpretation by each individual of the code of honour which he chose to apply to the solution of his own particular case. Duelling became a mere exhibition or assertion of personal vanity; and a breach of the smallest ceremony or punctilio was an excuse for drawing the sword which every gentleman then wore.

This was the practice which James I denounced in the edict penned by his own hand in $\mathrm{I}^{6} \mathrm{I} 3$ as 'that saucie Paradox which gives liberty to gentlemen with their owne Swordes to revenge wrongs done to themselves,' and of which his Attorney-General, Sir Francis Bacon, declared:

' for a difference to be made in case of killing and destroying man upon a fore-thought purposes between foul and fair, and as it were between single murder and vied murder, it is but a 
monstrous child of this latter age, and there is no shadow of it in any law divine or human.' 1

To this period belong the duels, which are so difficult to distinguish from street-brawls, and cold-blooded assassinations; for these frays lacked the deliberate arrangement, ceremony, and intentional fair play of the duel. My friend, Mr. Hubert Hall, informs me that the Records of Ancient Indictments, Assize and Sessions Records are full of such cases right up to the nineteenth century; and our President, Professor Firth, has been kind enough to furnish me with a typical case in January I659, when Francis Wortley, a gentleman of the Middle Temple, was slain by the Earl of Chesterfield at Kensington, because the latter was dissatisfied with a mare which he had insisted on buying without any guarantee whatsoever. It may be noted that one of the Protector's ordinances declared duelling ' unpleasing to God, unbecoming Christians, and contrary to all good order and government.' A person sending a challenge was to be bound over to keep the peace for six months, and a duellist who killed his opponent was to be tried for murder. ${ }^{2}$

The repression of duelling was nowhere more earnestly attempted than in France under such strong and wise ministers as Sully, Richelieu, and Mazarin.

We know, however, that Richelieu failed to put an end to duels, in spite of the severe execution of his edicts. The ostentatious execution of certain offenders in 1627 caused an immense sensation; but this was an isolated fact. Duels continued from this period to the end of the Fronde with the same intensity as under the reign of Henry IV. They only diminished and disappeared gradually towards the latter years of Mazarin's government, although he hardly took any strong measures against them. The

1 See Worke for Cutlers (Camb. Univ. Press, 1904) for facsimile of proclamation (Soc. of Antiq.), and pp. 30 and 83-85.

2 Prof. C. H. Firth's Oliver Cromwell (Putnam Sons, I900), p. 350. See also his 'A Restoration Duel,' Scottish Hist. Review, Oct. I905. 
fashion, or rather the change of manners, alone effected what the royal will had been powerless to realise.

Every year to the end of the reign of Louis XIII we read of a number of sensational duels, all unpunished, although several took place in the King's own palace. The Sovereign closed his eyes. Under the Regency of Anne of Austria 930 gentlemen were notoriously killed in duels, without reckoning those who thus perished, but whose deaths were officially attributed to other causes. 'Now the duels of those days in no way resemble those of our own day. Much more frivolous in their pretexts, they were much more serious in their results. They were not the minutely regulated ceremonies where every precaution is taken to equalise the chances or to avoid an "accident" ; they were real battles, struggles of barbarians with their diabolic fury, their disloyal ruses, their implacable cruelty. The champion who falls is always "fairly slain" whatever happens; a Sieur de Boësse, a brave but cruel gentleman, had killed seventeen persons in duels, and a Chevalier d'Audrieux seventy-two.' 1

Through all generations duelling has been a matter of class and caste; and one of the still vexed questions in connection with it was always whether a challenge could be accepted when it proceeded from a man of lower rank than the person challenged. In fact, 'you punctiliously proved yourself to be a man of blood by shedding another man's.' Jeremy Collier, the author of the 'Short View of the Profaneness of the English Stage,' as indicated by John Dryden's plays, sharpens his satire upon the stone that it was not becoming for gentlemen to manage their quarrels like other people. 'Their revenges must be particular as well as the rest of their breeding ' - so that, if Butchers had but the manners to go to "Sharps" (i.e. swords) Gentlemen would be contented with a rubber at cuffs '; and he further makes the shrewd observation that the 'custom of duels puts gentlemen upon their good

1 Lavisse, Hist., V. iv. 357 . 
behaviour.' Moreover, he observes that to give the lie was not counted so brutal an affront till Charles $\mathrm{V}$ happened to say he was no gentleman who would take it; and he asks, 'What has England to do with Germany?' 1

Brantôme has been called the Justinian of the Duelling Digest-and it will be interesting to consider some of the points of his code, which is not of a high moral stamp. He cautions duellists against fighting without swords, as was done sometimes in Italy in the contests called 'Mazza' (or Mace). His reasons are, first, that it is depriving the public of a fine spectacle; and, secondly, it exposes the survivor to the risk of being tried or punished as a murderer. An unbeliever should not be chosen as a second, because it is not right that an infidel should see Christian blood shed. The combatants ought to be carefully searched, to ascertain that they bore no 'drogueries, sorceleries ou maléfices'-but relics of Notre Dame de Lorette were allowed to be worn. Courtesy was not to be spoken ofit was out of place for any one who entered the 'champ clos,' and who was prepared to conquer or die. The victim was at the victor's disposal, to be dragged through the camp, hanged, burnt, or kept prisoner: Achilles dragging Hector at the tail of his chariot was the classic example to be followed.

On the other hand, every gallant knight must uphold a lady's honour, whether she had forfeited it or not. A soldier might fight his captain-provided the former has had two years' service and demands to leave his company ; but others disagree with this view. ${ }^{2}$ If a father accuses his son of dishonourable conduct, the son might challenge his father to a duel. All this etiquette was handed down to later generations of fine gentlemen who indulged their instinct of ' wild men' with boundless effrontery.

1 Essays upon Several Moral Subjects, 7th ed., I732.

2 Basnage, De Singulari Certamine, ch. xxvii.; A. Alciatus, De Singulari Certamine... in materia Duelli (1543, Lugd. Giunta); La Béraudière, Du Combat de Seul a Seul (pt. ii. ch. vii. p. I6) is of Brantôme's opinion.

T.S.-VOL. XI. 
The Comte de Châtauvillard ${ }^{1}$ was the first to carry out the idea of codifying laws of the duel (I836), and he prefaces his attempt with this justification :

'If the code of the duel is outside the laws, if there can be no code other than that sanctioned by the law, nevertheless let us not hesitate to give the name to the rôles imposed by honour, for honour is no less sacred than the laws of the State.'

De Châtauvillard's Code was backed by all the authority of the army, from marshals down to captains, as the imposing list of military signatories shows, but, unfortunately, it had a formidable civilian rival in an unpublished code of honour and custom, and here again we see that a military caste had not a monopoly of this institution.

'Never,' writes M. Alfred Rambaud, ${ }^{2}$ was there so much duelling as in the first years of the Restoration (1814-I848); officers of the old Imperial Guard and of the new Royal Guard "went out" every morning. The race of professional duellists reappeared. Parliamentary duels, as a consequence of discussion in the Chambers, were frequent (such as that of General Foy and M. de Corday), usually determined with pistols.'

In some instances an outbreak of duelling would seem to be one of the results of war, perhaps by way of reflex action; or of a great battle, for after Waterloo we observe recorded in such books as Raikes's 'Journal' the attack of a fresh epidemic of duelling. This may be partially accounted for by the change of dynasty in the restoration of the Bourbons, but I am more inclined to attribute it to the waves of unrest and excitement set in motion by the Napoleonic wars, which could only subside by degrees.

Gronow's gossiping but reliable volumes are crowded with duelling stories, the scene being mostly laid in France, after the Restoration of the Bourbons. ${ }^{3}$ The English

1 Essai sur le Duel, Paris, 8vo, 1836 (full translation into German by C. von L. Karlsruhe, I888, fifty yeais after its promulgation).

2 Histoire de la Civilisation Contemporaine de France.

3 Recollections and Anecdotes, I728-73. 
officers were as keen to show their metal as the French officers of Napoleon's army and the Bourbonists of the Garde $d u$ Corps. Then there were the Russian, Prussian, and Austrian officers, the latter being nearly always the aggressors in their duels with the French. At Tortoni's Café on the Boulevard a room was set apart for these fireeaters to cool themselves with ices and champagne after their meetings. Gronow speaks of an Irishman in the Garde $d u$ Corps who was said to have killed nine opponents in one year.

In Germany, if the duel figures less prominently in the political and social annals of the seventeenth and eighteenth centuries, it is nevertheless associated with a very definite state policy which is responsible for the regularisation of these combats in the eighteenth century, and perhaps also for their perpetuation in modern times.

In September I670 the Kurfürst of Mainz laid before the Diet an imperial decree of I668 that every one was to refrain from duelling throughout the Holy Roman Empire. The authorities were to arrest all who took part in 'Balgereien' or frays; and innkeepers and fathers of families, authorities at universities and academies were to give immediate notice of such occurrences, and all sorts of penalties were to be imposed; but the customs and prejudices of the time prevented the decree from being much more than a dead letter. As Frederick the Great shrewdly remarked, the edicts against duelling were well-intentioned, but the much older prejudices were stronger than the law.

In a Cabinet order of May 2I, I79I, on Courts of Honour, King Frederick William II expressed his opinion that such courts would probably only lead to an extension of duelling, and would have many prejudicial effects upon the esprit de corps both in the army and among civilians of the nobility. But in 1803 , Frederick William III imposed these Courts of Honour upon the officer corps of the standing army (August 3, I808) and in I8I6 upon the militia. Frederick William IV in I843 extended the powers of the 
Courts of Honour by giving them full control over the duel throughout its procedure, in the event of failure to compose the quarrel. This order was annulled by the German Emperor, William the First, in 1874 , 'in the confidence that noble manners and good tone will be maintained in the officers' corps '; but an officer who was challenged was still required to give notice to the 'Ehrenrath,' or Council of Honour, whose duty it became to attempt a reconciliation, and if this failed, to see that the conditions of the duel were in no way out of proportion to the gravity of the incident. The President, or a member of the Honour Council, had to be present as a witness to see that the duel was conducted according to the 'Standes-Sitte,' or class custom. Proceedings in the Court of Honour were only to be taken against officers engaging in a duel when a breach of the 'Standes-ehre' (or class-honour) was committed by either party. This cautious attitude of the army authorities towards duelling was further complicated by the ambiguous and oft-quoted declaration of the Kaiser, in concluding his Imperial Rescript : 'An officer who is capable of injuring a comrade wantonly I will as little tolerate in my army as an officer who does not know how to protect his honour.'

Should an officer be insulted by a civilian, this had to be forthwith brought before the Council of Honour. If an officer resorted to arms against a civilian's insult or illtreatment, he was bound to draw blood to satisfy his militaristic honour, but he easily procured pardon, and he would be either acquitted or receive only nominal punishment from the Court Martial sitting on the case. ${ }^{1}$

The opinion that the duel keeps alive personal courage is largely held by the Germans, and on this point my friend Professor Mahaffy, Provost of Trinity College, Dublin, writes to me that the present German Emperor once argued with him 'that he thought it was worth while keeping up duelling to promote individual courage, and in cases

1 Vide Professor Sharpe, 'The Making of a Gentleman in Germany, Contemp. Review, October r9r6. 
where, a lady being concerned, law suits are odious and often unjust.' 1

Professor Paulsen, in his well-known work on 'The German Universities,' gives a qualified approval of the 'Mensur'2 on the ground that fencing is a form of physical exercise-and the Schläger-duel is also

'a practice and proof of courage, not, indeed, of the highest kind, but nevertheless of a certain control of the will over the physical body-and also that it assists in giving a person a position among his own kind, which depends upon personal merit, and not upon the size of his purse. The rapier puts all upon an equal footing.' 3

However, so far as our country was concerned, the end of duelling was not far off. Lord Campbell, writing not much more than half a century ago, ${ }^{4}$ could remember the time when almost all the parliamentary leaders on both sides had 'been out'; but he could not call to mind a single surviving leader who had exchanged balls as well as words with a rival.

We used to be told that without duelling there would be intolerable scurrility in debate, but no such consequence has followed its abolition. This experience would seem to dispose of De Quincey's contention that the absence of duelling amongst the Greeks and Romans led to the extreme licence allowed in speech both in the Agora and Forum and in private life. ${ }^{5}$

The adjustment of a quarrel by a declaration that certain offensive expressions had been used in a Pickwickian sense was suggested to Charles Dickens by a scene in the House of Commons in I823, when Brougham accused Canning of 'exhibiting the most incredible specimen of monstrous truckling for the purpose of obtaining office that the whole

1 Letter to A. F. S., December 1o, I9r6.

2 So called from the 'Measurement' of the distance between the combatants.

3 Fr. Paulsen, The Gevanan Universities, trans. E. D. Perry, I895, p. 377 ; and Sir Lees Knowles, A Day with Corps-Students in Germany.

' 'Life of Lord Brougham,' in Lives of the Chancellors, iv. 343.

s See De Quincey's article on 'Casuistry.' 
history of political tergiversation could furnish '-and was interrupted by Mr. Secretary Canning, 'I rise to say that that is false.' To avoid a duel a motion was made that both the honourable members should be committed to the custody of the Sergeant-at-Arms; whereupon Brougham explained at some length that he meant the expression to be understood in a parliamentary and not in a personal or party sense.

In the session of June I824 the House devised a new expedient for preventing duels among the members by treating every outrage which might provoke a challenge as proof of insanity.

In the very first year of Queen Victoria's reign a statute ${ }^{\mathbf{1}}$ was enacted to amend Lord Lansdowne's Act, ${ }^{2}$ which had repealed the Black Act ${ }^{3}$ and Lord Ellenborough's Act ${ }^{4}$ extending it. The third section of the Act of 1838 made it a felony to shoot at any person, or to attempt to discharge any kind of loaded arms, with intent to commit a crime of murder, the accused upon conviction to be transported for life or for any term not less than fifty years.

In the House of Lords (transformed into the Lord High Steward's Court) on February I8, I84I, took place the mock trial of the Earl of Cardigan for firing with a loaded pistol at Harvey Garnett Phipps Tucket (much hinged upon this name) with intent to murder him, also with intent to maim and disable him, also with intent to do him some grievous bodily harm. The Attorney-General, in his speech for the prosecution, stated that it was sixty-four years (i.e. I777) since any proceedings of this sort had taken place, and amongst the statutes cited were the 5 Henry IV, c. 5 , and the Coventry Act ( $22 \& 23$ Charles II), whereby any person lying in wait for and wounding with intent to maim or to disfigure was guilty of felony, without benefit of clergy.

Fortunately there was a woman on the throne, and a Bentham in the study, to sweep the cobwebs and the dust

1 I \& 2 Vict., c. 85.

s 9 Geo. IV, c. 2 r.
29 Geo. I, c. 2.

443 Geo. III, c. $5^{8}$. 
of ages from this full-bottomed big-wiggery; and in 1843 , after royal and public attention had been drawn to the question by a duel at Camden Town on July I, in which Colonel Fawcett was shot by his brother-in-law, Lieutenant Munro, who had gone out after great provocation-an influential Anti-duelling Association was formed, greatly influenced by Bentham's powerful public and private reasoning. ${ }^{1}$ At the same time the Duke of Wellington, acting on Prince Albert's suggestion, submitted to Queen Victoria a General Order for the suppression of duelling in the army and navy, and the Articles of War were amended accordingly.

The time at my disposal has not permitted me to make any mention of laws or customs of the Scandinavian nations or of the great part which the duel plays in the national life of Italy and Spain, whilst the history of duelling in Ireland is of political as well as social interest. Finally, the military aspect of the subject could be illustrated from the procedure of Courts Martial and other departmental records. ${ }^{2}$

If time had permitted, I should also have liked to cite many British and foreign writers whose opinions with regard to the customs of duelling are of considerable interest. Amongst the former Lord Herbert of Cherbury, Smollett, Dr. Johnson, Grattan, O'Connell, and Tom Moore have many instructive remarks to offer on this subject, but they do not take us very far in an attempt to trace some connection between duelling and militarism. Nor was it to be expected that they should do so: for, in the first place, standing armies and martial law, which is necessary for the maintenance of discipline, have always been regarded

1 Bentham's influence can be perhaps even better measured from his private correspondence (e.g. with the Duke of Wellington) than from his public utterances (see Index to Bowring's edition of his works).

2 For this subject see especially Capt. H. James's Regimental Companion and Collection of Charges, \&c., extracted from the records of the Judge Advocate-General's Office (1820), and The Letters of Queen Victoria, edited by A. C. Benson and Lord Esher, i. $45^{\circ}$ and $4^{85}$. 
as an extraordinary expedient outside the pale of the ancient constitution of the realm and subject to the control of the civil power. In the second place, the more familiar aspects of militarism are found in the period since the Franco-German War of I870. Under our insular and democratic form of government the duel has only been a temporary manifestation of the passionate weakness of our human nature, now almost incredible to us; whilst militarism or any other system that denotes the political or social domination of a military caste, or even the cult of warlike ideals, offensive or defensive, is equally repugnant to a nation which for good or evil has clung to the laws and customs and methods of its forefathers.

\section{APPENDIX}

Professor Bury has been kind enough to furnish me with the following valuable notes on Roman challenges (ante, pp. I67-8) :

'The instances which we have in Roman history like the Spaniard's challenge which Scipio took up at Intercatia, or that of the Goth Ularis which the Persian Artabazes took up in the Ostrogothic war of Justinian, are instances of Celtiberian and Germanic customs. (I do not understand the case of Octavian, Cæsar and Antony.) There is one case that you should be careful about, the alleged Zweikampf of the Roman generals Aetius and Boniface in the fifth century. Either it is a legend, or else, as 1 have suggested, they fought hand to hand in a battle-there was certainly a battle between the troops. You will see something about this in an Appendix to my edition of Gibbon (vol. iii.).

'The Leges Longobardorum seem to be the most interesting of the Germanic laws, as to Camfio as one of the legal ways of settling disputes.' (Letter to A. F. S., Dec. 8, r9r6.) 